\title{
Critical minimum temperature limits xylogenesis and maintains treelines on the southeastern Tibetan Plateau
}

\section{Citation}

Li, Xiaoxia, Eryuan Liang, Jozica Gricar, Sergio Rossi, Katarina Cufar, and Aaron M. Ellison. 2017. "Critical Minimum Temperature Limits Xylogenesis and Maintains Treelines on the Southeastern Tibetan Plateau." Science Bulletin 62 (11) (June): 804-812. doi:10.1016/j.scib.2017.04.025.

\section{Published Version}

doi:10.1016/j.scib.2017.04.025

\section{Permanent link}

http://nrs.harvard.edu/urn-3:HUL.InstRepos:33444606

\section{Terms of Use}

This article was downloaded from Harvard University's DASH repository, and is made available under the terms and conditions applicable to Other Posted Material, as set forth at http:// nrs.harvard.edu/urn-3:HUL.InstRepos:dash.current.terms-of-use\#LAA

\section{Share Your Story}

The Harvard community has made this article openly available.

Please share how this access benefits you. Submit a story.

\section{Accessibility}




\section{Critical minimum temperature limits xylogenesis and maintains treelines}

\section{3 on the southeastern Tibetan Plateau}

\section{Xiaoxia Li • Eryuan Liang • Jozica Gričar • Sergio Rossi • Katarina Čufar • Aaron M. Ellison} 5

$6 \quad$ X. Li • E. Liang

$7 \quad$ Key Laboratory of Alpine Ecology and Biodiversity, Key Laboratory of Tibetan Environment Changes

8 and Land Surface Processes, Institute of Tibetan Plateau Research, Chinese Academy of Sciences,

$9 \quad$ Beijing 100085, China

10 E. Liang

11 CAS Center for Excellence in Tibetan Plateau Earth Sciences, Beijing 100101, China

12 J. Gričar

13 Slovenian Forestry Institute, Department of Yield and Silviculture, Vecna pot 2, SI-1000 Ljubljana,

14 Slovenia

15 S. Rossi

16 University of Quebec in Chicoutimi, Département des Sciences Fondamentales, 555, Boulevard de

17 l'Université, Chicoutimi (QC) G7H2B1, Canada ;

18 Key Laboratory of Vegetation Restoration and Management of Degraded Ecosystems,

19 Guangdong Provincial Key Laboratory of Applied Botany, South China Botanical Garden,

20 Chinese Academy of Sciences, Guangzhou 510650, China

21 K. Čufar

University of Ljubljana, Biotechnical Faculty, Department of Wood Science and Technology,

23 Jamnikarjeva 101, SI-1000 Ljubljana, Slovenia

24 A. M. Ellison

25 Harvard Forest, Harvard University, 324 North Main St., Petersham, Massachusetts 01366, USA 26

27 Corresponding author (email: liangey@itpcas.ac.cn) 


\section{Abstract}

30 Physiological and ecological mechanisms that define treelines are still debated. It has been suggested

31 that the absence of trees above the treeline is caused by low temperatures that limit growth. Thus, we 32 hypothesized that there is a critical minimum temperature $\left(\mathrm{CT}_{\min }\right)$ preventing xylogenesis at treeline.

33 We tested this hypothesis by examining weekly xylogenesis across three and four growing seasons in 34 two natural Smith fir (Abies georgei var. smithii) treeline sites on the southeastern Tibetan Plateau.

35 Despite differences in the timing of cell differentiation among years, minimum air temperature was

36 the dominant climatic variable associated with xylem growth; the critical minimum temperature

$37\left(\mathrm{CT}_{\min }\right)$ for the onset and end of xylogenesis occurred at $0.7 \pm 0.4{ }^{\circ} \mathrm{C}$. A process-based modelling

38 chronology of tree-ring formation using this $\mathrm{CT}_{\min }$ was consistent with actual tree-ring data. This

39 extremely low $\mathrm{CT}_{\min }$ permits Smith fir growing at treeline to complete annual xylem production and

40 maturation and provides both support and a mechanism for treeline formation.

41

42 Keywords: Cambial activity $•$ critical minimum temperature $•$ timberline $\bullet$ xylem $•$ Vaganov-Shashkin 43 model 
The explanations for treeline formation focus on limitations of available resources [1, 2], establishment sites [3], or time available for growth [4], although these ecophysiological causes remain debated [5-8]. Based on notable similarities in temperatures at treelines [9], the growth limitation hypothesis proposed that low temperatures limit the time available for meristematic growth and cell division $[4,10]$. This hypothesis has been supported by phenomenological data. For example, treeline trees tend to have higher amounts of non-structural carbohydrates than trees growing at lower elevation, suggesting that treeline is limited more by growth processes than by photosynthesis and carbon assimilation [11-13]. In parallel, dendroclimatic studies have identified a signal of reduced growth during periods with low temperatures at treelines in cold and humid areas [14-17].

Physiological manifestations of the growth limitation hypothesis include a constraint on the production of new cells by meristems below a critical minimum temperature $\left(\mathrm{CT}_{\min }\right)[4]$ and a trade-off between taking maximal advantage of the length of the growing season while avoiding cellular damage due to early (fall, winter) or late (winter, spring) freezing events [18-19]. Such a trade-off would suggest a narrow thermal window for the onset and cessation of xylogenesis at treeline and recent studies have described temporal dynamics in xylogenesis of various tree species at treeline [20-24]. Some studies reported that a gradual increase in temperature (heat sum) was associated with the onset of cambial activity [21, 25], whereas others estimated a $\mathrm{CT}_{\min }$ of 6 - $8{ }^{\circ} \mathrm{C}$ for xylogenesis at the altitudinal treeline in the Eastern Alps [20, 26]. Separating gradual (heat-sum) and threshold $\left(\mathrm{CT}_{\min }\right)$ effects on xylogenesis at treeline has not yet been accomplished.

A mechanistic model can provide a deeper understanding on the climatic control on tree growth dynamics. The process-based Vaganov-Shashkin (VS) model has been used to simulate climatic controls on conifer tree-ring growth [27-29]. In the VS model, the critical temperature for cambial activity is a key parameter for modelling tree growth, but there are limited data available to estimate this parameter.

Our observations at the upper treeline of Smith fir (Abies georgei var. smithii) on the southeastern Tibetan Plateau, including a decade of uninterrupted in situ micrometeorological measurements and weekly collection of microcores containing cambium activity and wood formation during three consecutive growing seasons provide an opportunity to examine both gradual and threshold effects of 
thermal control of xylogenesis to be a mechanism underlying the growth limitation hypothesis by (1) identifying the timing and dynamics of xylogenesis in Smith fir growing at treeline as a function of climatic factors; and (2) detecting a plausible $\mathrm{CT}_{\min }$ for xylogenesis. Previous studies have found that the growth of Smith fir near treeline is constrained by the minimum temperature in summer [30, 31]. The onset of bud swelling and needle unfolding in Smith fir is delayed by 3.5 days for each 100-m increase in elevation [32], indicating a thermal limitation of tree phenology. Therefore, we hypothesized that minimum temperature limits xylogenesis and that a threshold minimum temperature controls the timing of the onset and ending of xylogenesis.

\section{Materials and methods}

\subsection{Study sites and tree selection}

We studied the natural alpine treeline of Smith fir growing on the eastern side of the Sygera Mountains $\left(29^{\circ} 10^{\prime}-30^{\circ} 15^{\prime} \mathrm{N}, 93^{\circ} 12^{\prime}-95^{\circ} 35^{\prime} \mathrm{E}\right)$ on the southeastern Tibetan Plateau [33]. The southeastern Tibetan Plateau is characterized by a cold and humid climate, and has the highest natural treeline (up to 4900 m a.s.l.) in the Northern Hemisphere [34]. Smith fir is a shade tolerant tree species and is one of the dominant treeline species in this region. The upper treeline position depends on topographic aspect and ranges from 4250 to $4400 \mathrm{~m}$ a.s.l. We studied two sites at open-canopy treelines: site 1 was at $4360 \mathrm{~m}$ a.s.l. on an east-facing slope, and site 2 was at $4250 \mathrm{~m}$ a.s.l. on a southeast-facing slope. The sites were $200 \mathrm{~m}$ apart, on slopes $<15^{\circ}$. Rhododendron aganniphum var. schizopeplum dominated the understory. The coverage of Smith fir was $<20 \%$ and the podzolic soils had an average $\mathrm{pH}$ value of 4.5 .

At each site, five dominant trees were selected in April 2007. These trees had a mean age of 201 \pm 24 and $117 \pm 14$ years, and mean diameters at $1.3 \mathrm{~m}$ aboveground of $34 \pm 4$ and $44 \pm 7 \mathrm{~cm}$ in sites 1 and 2, respectively. Because repeated sampling could cause severe wounding that could modify xylogenesis, another five trees per site with similar diameters at breast height were chosen for samplings in 2009 and 2010. Trees with polycormic stems, partially dead crowns, reaction wood, or other evident damage were avoided.

\subsection{Meteorological data}

An automatic weather station (Campbell Scientific, CR1000) was installed in November 2006 in an 
open area above the treeline $\left(29^{\circ} 39^{\prime} \mathrm{N}, 94^{\circ} 42^{\prime} \mathrm{E}, 4390 \mathrm{~m}\right.$ a.s.1.) at a linear distance of $\approx 150 \mathrm{~m}$ and 200 $\mathrm{m}$ from sites 1 and 2, respectively. Measurements of air (3 m aboveground) and soil temperature (at 10-, 20- and 40-cm depths), precipitation, snow fall, and soil water content (at 10-, 20-, and 40-cm depths) were collected at 30-minute intervals. These data were used to compute daily averages, minima, and maxima of each variable.

\subsection{Microcoring and histological analyses}

112 Xylem growth was studied from 2007 until 2010 at site 1 and from 2007 to 2009 at site 2. One

113 microcore (15-mm long, 2-mm diameter) was collected from each tree weekly from May until

114 October around the stem at breast height (1.3 m aboveground) using a Trephor tool. Immediately after

115 removal from the trees, the microcores were fixed in a formalin-ethanol-acetic acid (FAA) solution.

116 The microcores contained innermost phloem, cambium, developing xylem, and at least three previous

117 xylem growth rings. In the laboratory, the microcores were dehydrated with successive immersions in

118 a graded series of ethanol and $d$-limonene, then embedded in paraffin. Transverse sections (9-12 $\mu \mathrm{m}$

119 in thickness) were cut from the samples with a Leica RM 2245 rotary microtome using Feather N35H

120 knives (Osaka, Japan). Sections were stained with a mixture of safranin (0.5\% in $95 \%$ ethanol) and

121 astra blue (0.5 \% in 95\% ethanol) and observed with a Nikon Eclipse 800 light microscope under

122 bright field and polarized light to identify the phases of differentiation of the developing xylem cells

123 [35]. In cross-section, cambial cells were characterized by thin cell walls and small radial diameters

124 [36, 37]. Newly-formed xylem cells in the phase of cell enlargement contained protoplasts, had thin

125 primary walls, and a radial diameter at least twice the size of the cambial cells [38]. The onset of

126 cell-wall thickening was determined by birefringence in the cell walls under polarized light. Mature

127 cells had completely red-stained walls and empty lumen. For each sample, the total current xylem cell

128 number was determined by counting the number of cells undergoing enlargement, cell-wall thickening,

129 and the number of mature cells along three radial files.

\subsection{Data standardization and fitting of xylem growth}

132 The data were standardized to compensate for variation in the number of xylem cells along the tree

133 circumference. The total cell number of the previous years was counted on three radial files per 134 sample and used for standardization. The standardized number of cells $n c_{i j}$ in the $i^{\text {th }}$ phase of the $j^{\text {th }}$ 
sample was calculated as:

$$
n c_{i j}=n_{i j}\left(a_{m} / a_{j}\right)
$$

where $n_{i j}$ is the number of cells in the current year, $a_{m}$ is the mean number of cells of the previous ring of all $j$-samples, and $a_{j}$ is the mean number of cells of the previous ring in each $j$-sample .

We modelled the dynamics of xylem growth by fitting a Gompertz function to the number of xylem cells that were produced through time:

$$
y=A \exp \left[-\mathrm{e}^{(\beta-\kappa t)}\right]
$$

where $y$ is the weekly cumulative sum of tracheids, $t$ is the time of the year computed as day of the year, $A$ is an asymptote (constant), and $\beta$ and $k$ are constants reflecting the $x$-intercept placement and rate of change, respectively. Model parameters were estimated using the Origin software package (Version 8.5, OriginLab Corporation, Northampton, MA, USA).

\subsection{Estimation of the onset and ending of xylogenesis}

We used observations of cell differentiation to identify the onset, ending, and duration of xylogenesis from counts of the number of cells in three radial files per tree. In spring, xylogenesis was considered to have started when at least one tangential row of cells was observed in the enlarging phase. Because of the weekly resolution of the monitoring, we used the occurrence of 1-2 enlarging xylem cells along any of the checked three radial files as an indicator the xylogenesis had begun [35]. In late summer, when cells were no longer observed in the wall thickening and lignification phase, xylogenesis was considered to have ended. The duration of xylogenesis was estimated as the number of days between the dates of onset and ending of xylogenesis.

Comparisons between sites in onset, duration, and ending of differentiation in the developing xylem ring were done with generalized linear models (GLM). Homoscedasticity was checked using Shapiro-Wilk and Levene tests.

\subsection{Identifying $\mathrm{CT}_{\min }$}

Logistic regression (LOGISTIC procedure in SPSS 16.0) was used to model the probability of xylogenesis as a function of air temperature. Xylogenesis was coded as zero (not occurring) or one (occurring). $\mathrm{CT}_{\min }$ was estimated as that temperature for which the probability of ongoing xylem growth equalled 0.5 [39]. For each tree and year, the model was fitted with three respective daily 
temperature series (mean, minimum, and maximum). Therefore, the $\mathrm{CT}_{\min }$ represents the critical night

167 regression parameter and goodness of fit, and Hosmer-Lemeshow $\hat{C}$ for possible lack of fit. None of

168 the models were excluded because of a lack of fit. $\mathrm{CT}_{\min }$ values were compared between sites and years using analysis of variance (ANOVA) models. Model validation was performed by comparing

170 the observed and predicted $\mathrm{CT}_{\min }$ values. Degree-day sum (DD) is an index representing a measure of accumulated heat. In spring, accumulation of DD began when daily air average temperature $\geq 5^{\circ} \mathrm{C}$ for

172 five consecutive days. The temperature $5^{\circ} \mathrm{C}$ is a commonly used standard in calculating the effective

173 heat sum in agriculture and forestry [40].

\subsection{Climate-growth relationships}

176 We used two approaches to identify relationships between intra-annual xylem growth and climatic

177 variables during four growing seasons. One approach consisted of computation of Pearson’s correlation coefficients between xylem cell production and weather data for weekly intervals. Weather data here include daily mean, daily absolute minimum, daily absolute maximum temperatures, growing degree-days (GDD) $>5^{\circ} \mathrm{C}$, and sums of precipitation. and exogenous factors (e.g., climate). To analyse the climatic effect, a common approach was used to remove the endogenous growth trend by fitting a growth curve, and to estimate the growth departure, calculated as the dimensionless ratio between observed and expected growth [41]. This ratio (hereafter called the 'growth index') was calculated as the number of tracheids produced during the week divided by the expected values estimated using the Gompertz function [42]. To account for possible effects of time-lags, daily weather data were averaged (temperature) or summed (precipitation) weekly from 1 to $10 \mathrm{~d}$ prior to each sampling date (referred to as P1 to P10). To minimize the effects of temporal autocorrelation, correlation coefficients were calculated on first-order differences for both datasets.

\subsection{Tree-ring modeling}

193 We used the Vaganov-Shashkin (VS) model to simulate tree-ring growth at the Smith fir treelines in 
the Sygera Mountains. The VS model estimates xylem growth and its internal characteristics based on equations relating daily temperature, precipitation, and sunlight to the kinetics of xylem development [43]. It assumes that climatic influences are directly but nonlinearly related to tree-ring characteristics through controls on the rates of cambial activity processes. To date, it has been successfully used to simulate and evaluate the relationships between climate and tree-ring formation under a variety of environmental conditions in many different regions [28, 29, 44-47]. Values from field observations were used for input parameters needed by the VS model: soil moisture, depth of root system, temperature sum for initiation of growth, soil water drainage rate, and maximum daily precipitation infiltrating into soil. We used our estimates of $\mathrm{CT}_{\min }$ as the starting value for the minimum temperature parameter. Model fit was evaluated against an actual tree-ring width chronology from Smith fir treeline in the Sygera Mts., which had been developed and used for paleoclimatic reconstructions in this region [31]. The best estimate of physiological $\mathrm{CT}_{\min }$ was found by iteration and comparison between simulated and observed chronologies (1960 - 2006).

Finally, a single simulated tree-ring width chronology was created for the Smith fir treeline in the Sygera Mts. based on daily climate data from the Nyingchi meteorological station (3,000 m a.s.l.). To account for the altitude differences between Nyingchi and the study sites, we extended the time series of daily temperatures at the treeline back to 1960 based on a linear regression of the Nyingchi data and our own micrometeorological data ( $r \geq 0.89,2007-2010$, Supporting Information Fig. S1).

\section{$213 \quad 3$ Results}

\section{$214 \quad 3.1$ Micrometeorological conditions at the upper treeline}

215 The sampling sites at the upper treeline were cold and humid. Despite a difference of $110 \mathrm{~m}$ in

216 elevation and different topographical aspects of the two treeline sites, they had similar temperatures

217 (Supporting Information Fig. S2). Annual average temperatures (2007 - 2010) ranged from 0.1 to 0.9

$218{ }^{\circ} \mathrm{C}$, while growing-season (June-September) temperatures ranged from 6.4 to $7.1^{\circ} \mathrm{C}$ (Fig. 1). On

219 average, annual precipitation was $951 \mathrm{~mm}$, of which $62 \%$ fell during the monsoon season (June to

220 September). Snowfall occurred mainly from November to May. Because of snowmelt and increased

221 precipitation, soil moisture content increased rapidly from the beginning of April and remained above

$22230 \%$ from early May until November, and finally decreased to near zero in late November and early

223 December. The year 2008 was characterized by heavy spring snowfall and had the latest snowmelt 
and soil thawing during the four studied years (Fig. 1).

\subsection{Xylogenesis}

227 The onset of xylogenesis occurred from late May to early June and differed significantly among years $228(F=15.73, P<0.001)$. The onset of xylogenesis was observed $4-9$ days later in 2008 than in the 229 other years, at both sites (Fig. 2 a). No difference was found in onset of xylogenesis between sites ( $F$ $230=2.31, P>0.05)$. Xylogenesis ended between the beginning and the end of September and differed significantly among years $(F=10.42, P<0.005)$, and occurred $1-2$ weeks later in 2010 at site 1 (Fig. 2 b).

Overall, the duration of xylogenesis lasted from 109 to 125 days (Fig. 2 c), with no significant differences detected between sites $(F=3.80, P>0.05)$. Conversely, there were significant variations among years $(F=4.71, P<0.05)$. From 2007 to 2009, the average period between the onset and ending of xylogenesis was 113 days, whereas the average of 125 days was required to complete xylogenesis in 2010.

\subsection{Relationship between climate and xylem growth}

Weekly cumulative xylem production was fit well by the Gompertz function $\left(0.96 \leq r^{2} \leq 0.98\right.$; Supporting Information Table S1 and Fig. S3). Intra-annual xylem cell production was significantly and positively correlated with daily minimum and mean air temperatures and GDD $>5^{\circ} \mathrm{C}$ at both sites (Fig. 3 a, b). However, only minimum temperature was significantly correlated with growth indices after removing the growth trends (Figs. 3 c, d). At site 1, positive correlations between growth indices and minimum temperatures were found for time lags of $0-3$ days $(r=0.34, P<0.05)$, whereas the corresponding time lags were $7-10$ days at site $2(r=0.42, P<0.05)$. No significant correlations were found between xylem cell production or growth index and precipitation from P0 to P10.

\section{$3.4 \mathrm{CT}_{\min }$}

251 The critical minimum air temperature $\left(\mathrm{CT}_{\min }\right)$ at which there was a 0.5 probability that xylem formation was ongoing is shown in Fig. 4 and Table 1 for site 1 (2007 - 2010) and site 2 (2007 2009). The values for minimum, mean, and maximum temperatures of $0.6,4.0$, and $9.3^{\circ} \mathrm{C}$ were 
estimated for the onset of xylogenesis, whereas the corresponding values for the ending of xylem differentiation were $0.7,3.9$, and $9.0^{\circ} \mathrm{C}$. There were no differences among critical temperatures for

256 the onset and ending of xylogenesis (ANOVA, $P>0.05$ ), with values of $0.7 \pm 0.4,3.9 \pm 0.5$, and $9.1 \pm$ $0.6^{\circ} \mathrm{C}$ for the minimum, mean, and maximum temperatures, respectively. No significant differences were found between the two sites in terms of the estimated air temperature thresholds for the onset and ending of xylogenesis (ANOVA, $P>0.05$ ). The mean air temperature during the period of xylem formation at both sites was $6.8 \pm 0.4^{\circ} \mathrm{C}$.

Among years, degree-day sum until the onset of xylogenesis at site 1 ranged from 8-41 DD, whereas corresponding temperature sums ranged from 12-34DD at site 2 (Table 2). Accumulated heat sum from 1 January until onset of xylem growth varied strongly between study years at both sites $(F=$ 17.6, $P<0.01)$.

\subsection{Tree-ring modelling}

Initializing the Vaganov-Shashkin (VS) model with with an estimated $\mathrm{CT}_{\min }=0.7^{\circ} \mathrm{C}$ yielded a best-fit estimate of physiological $\mathrm{CT}_{\min }=0.9^{\circ} \mathrm{C}$ (Table 3, Fig. 5). The correlation between observations and predictions varied slightly for $\mathrm{CT}_{\min }$ of $0.3-1.0^{\circ} \mathrm{C}$, whereas it decreased rapidly for $\mathrm{CT}_{\min }>1{ }^{\circ} \mathrm{C}$ (Fig. 6). Overall, significant, positive correlations were found between the modelled and measured chronologies when $\mathrm{CT}_{\min }$ varied within the range of $0.7 \pm 0.4^{\circ} \mathrm{C}(r=0.62, P<0.01)$.

\section{Discussion}

274 The importance of temperature for xylogenesis during and after its onset has been demonstrated repeatedly [25, 37, 48-51]. These and other data suggest that air temperature, not soil temperature, directly limits xylogenesis at high latitudes and altitudes [20, 24, 52]. Minimum temperature is assumed to be an important driver of tree species range limits [7, 19], and so a critical minimum temperature $\left(\mathrm{CT}_{\min }\right)$ with narrow bounds should exist for the onset and ending of xylogenesis. However, long-term monitoring of xylem growth at natural treelines is limited, which has precluded assessment of $\mathrm{CT}_{\min }$ for xylogenesis by direct observations.

\subsection{Effects of climate on xylem growth}

283 As predicted, minimum air temperature strongly limited xylem growth of Smith fir at the upper 
treeline on the southeastern Tibetan Plateau. This finding agrees with those from dendroclimatological analysis in the same study area [31] and wood formation studies at high latitudes and altitudes [22, 37]. The importance of minimum air temperature may be related to the timing of cell differentiation, which may occur mainly during the night when the temperature is lower [53, 54]. Controlled experiments also showed that night temperatures could directly influence xylem cell expansion of Podocarpus latifolius [55]. According to Körner [7], cell doubling time, which is highest and fairly constant at temperatures of $10-25^{\circ} \mathrm{C}$, approaches infinity at $1-2^{\circ} \mathrm{C}$, suggesting a minimum temperature limit on cell division. The simulated ring-width chronologies produced by the VS model of tree-ring formation also exhibit similar positive correlations with the minimum temperature during summer (Supporting Information Fig. S4, $P<0.01$ ). $\mathrm{CT}_{\min }$ is thus expected to limit xylogenesis of Smith fir at the treeline.

\subsection{Critical temperatures for xylogenesis}

297 Our results suggest that threshold effects, not heat sum effects, play a key role in the onset of xylogenesis at Smith fir treeline. Despite the variance in timing and duration of xylogenesis during our four years of observations, minimum, average, and maximum temperatures for the onset and ending of xylogenesis were narrowly bounded with average values of $0.7,3.9$, and $9.1^{\circ} \mathrm{C}$, respectively.

Most studies to date have indicated that xylogenesis in conifers growing in cold climates can take

303 place when the daily minimum temperatures $\geq 4-5{ }^{\circ} \mathrm{C}[39,56]$. However, based on the presented

304 4-year observations of xylogenesis and uninterrupted in situ micrometeorological measurements 305 directly at the treeline, we found that the $\mathrm{CT}_{\min }$ for xylogenesis in Smith fir is as low as $0.7^{\circ} \mathrm{C}$. In 306 particular, based on this $\mathrm{CT}_{\min }$, the modelled chronology produced by VS model is consistent with 307 actual tree-ring data, suggesting that minimum temperature could be considered as a significant driver of xylem growth. Such a low $\mathrm{CT}_{\min }$ may have evolved to provide sufficient time to complete xylogenesis at alpine treelines. The length of the growing season for stem growth diminishes with altitude and reaches a minimum at the alpine treeline. According to some authors [10, 39], a tree can only survive when the growing seasons are at least 3 months long and the mean air temperature during

312 the growing season is $6.4{ }^{\circ} \mathrm{C}$; each of these constraints critically limit the growth and development of 313 trees. At Smith fir treelines in southeastern Tibet, the duration of xylem growth of 115 days provided 
314 by a $\mathrm{CT}_{\min }<1{ }^{\circ} \mathrm{C}$ and a mean air temperature of $6.8^{\circ} \mathrm{C}$ during the growing season extended by this

315 low $\mathrm{CT}_{\min }$ together meet these prerequisites for tree growth and development.

316 The dates of snow melting and soil thawing also are thought to be critical for the onset of

317 xylogenesis and could therefore determine the annual xylem production [27]. At our treeline sites, the

318 onset of xylem growth occurred 4-46 days after snow melting and 4-29 days after soil thawing in

319 spring, which coincided with the surpassing of $\mathrm{CT}_{\text {min }}$ (Table 2). This temporal lag also suggests that

320 threshold effects exist for the onset of xylogenesis at Smith treeline.

321 The growth limitation hypothesis predicts that the absence of trees above the treeline is

322 attributable to critical minimum temperature for growth [4]. Treeline trees often have slower growth

323 rates and higher non-structural carbohydrate levels than trees at lower altitudes [11-13], suggesting a

324 carbon sink rather than carbon gain limitation [57]. However, some authors have argued that tree

325 populations with the highest non-structural carbohydrate concentrations may be the most carbon

326 limited in terms of growth [58, 59]. Although our observations of xylogenesis cannot differentiate

327 between carbon limitation and a carbon sink in Smith fir, the significant effect of a narrowly bounded

$328 \mathrm{CT}_{\min }$ on xylem growth provides a physiological mechanism for the growth limitation hypothesis.

330 Acknowledgments This work was supported by the National Natural Science Foundation of China

331 (41525001, 41661144040, 41601204). International cooperation was supported by the bilateral project

332 between China and Slovenia (BI-CN/09-11-012) and COST Action (FP1106, STReESS). AME’s

333 participation in the project was supported by the Chinese Academy of Sciences President International

334 Fellowship Initiative for Visiting Scientists, Grant no. 2016VBA074. We thank the Southeast Tibet

335 Station for Alpine Environment Observation and Research, Chinese Academy of Sciences for the

336 fieldwork and monitoring; Yongxiang Zhang from National Climate Centre, Beijing, China for her

337 support on the VS model, and Martin Cregeen for additional language editing for an early version.

339 Conflict of interest The authors declare that they have no conflict of interest.

\section{References}

342 1. Stevens GC, Fox JF (1991) The Causes of Treeline. Ann. Rev. Ecol. Sys. 22: 177-191. 
2. Susiluoto S, Hilasvuori E, Berninger F (2010) Testing the growth limitation hypothesis for

344 subarctic Scots pine. J. Ecol. 98: 1186-1195.

345 3. Smith WK, Germino MJ, Hancock TE et al (2003) Another perspective on altitudinal limits of $346 \quad$ alpine timberlines. Tree Physiol 23: 1101-1112.

347 4. Körner C (1998) A re-assessment of high elevation treeline positions and their explanation.

$348 \quad$ Oecologia 115: 445-459.

349 5. Tranquillini W (1979) Physiological ecology of the alpine timberline. Springer, Berlin Heidelberg $350 \quad$ New York.

351

6. Holtmeier FK (2003) Mountain timberlines: ecology, patchiness and dynamics. Dordrecht, Kluwe.

7. Körner C (2003) Alpine plant life: functional plant ecology of high mountain ecosystems, 2nd edn. Springer, Berlin Heidelberg New York.

8. Cui H, Liu H, Dai J (2005) Study on mountain ecology and alpine timberline. Beijing, Science Press.

9. Körner C, Paulsen J (2004) A world-wide study of high altitude treeline temperatures. J. Biogeogr. 3: 713-732.

10. Körner C (2012) Alpine treelines: functional plant ecology of the global high elevation tree limits. Springer, Berlin Heidelberg New York.

11. Hoch G, Körner C (2003) The carbon charging of pines at the climatic treeline: a global comparison. Oecologia 135: 10-21.

12. Shi P, Körner C, Hoch G (2008) A test of the growth-limitation theory for alpine tree line formation in evergreen and deciduous taxa of the eastern Himalayas. Funct Ecol 22: 213-220.

13. Fajardo A, Piper FI, Hoch G (2013) Similar variation in carbon storage between deciduous and evergreen treeline species across elevational gradients. Ann Bot 112: 623-631.

14. Makinen H, Nojd P, Mielikainen K (2000) Climatic signal in annual growth variation of Norway spruce (Picea abies) along a transect from central Finland to the Arctic timberline. Can J For Res 30: 769-777.

15. Oberhuber W (2004) Influence of climate on radial growth of Pinus cembra within the alpine timberline ecotone. Tree Physiol 24: 291-301.

16. Frank D, Esper J (2005) Characterization and climate response patterns of a high-elevation, multi-species tree-ring network in the European Alps. Dendrochronologia 22: 107-121. 
17. Ettinger AK, Ford KR, HilleRisLambers J (2011) Climate determines upper, but not lower, altitudinal range limits of Pacific Northwest conifers. Ecology 92: 1323-1331.

18. Chuine I, Beaubien EG (2001) Phenology is a major determinant of tree species range. Ecol Lett 4: 500-510.

19. Kollas C, Körner C, Randin CF (2014) Spring frost and growing season length co-control the cold range limits of broad-leaved trees. J Biogeogr 41: 773-783.

20. Rossi S, Deslauriers A, Anfodillo T et al (2007) Evidence of threshold temperatures for xylogenesis in conifers at high altitudes. Oecologia 152: 1-12.

21. Seo JW, Eckstein D, Jalkanen R et al (2008) Estimating the onset of cambial activity in Scots pine in northern Finland by means of the heat-sum approach. Tree Physiol 28: 105-112.

22. Gruber A, Baumgartner D, Zimmermann J et al (2009) Temporal dynamic of wood formation in Pinus cembra along the alpine treeline ecotone and the effect of climate variables. Trees- Struct

23. Moser L, Fonti P, Büntgen U et al (2010) Timing and duration of European larch growing season along altitudinal gradients in the Swiss Alps. Tree Physiol 30: 225-233.

24. Lenz A, Hoch G, Körner C (2012) Early season temperature controls cambial activity and total tree ring width at the alpine treeline. Plant Ecol Diver 6: 365-375.

25. Jyske T, Makinen H, Kalliokoski T et al (2014) Intra-annual tracheid production of Norway spruce and Scots pine across a latitudinal gradient in Finland. Agric. For. Meteorol., 194:

26. Ziaco E, Biondi F, Rossi S et al (2016) Environmental drivers of cambial phenology in Great Basin bristlecone pine. Tree Physiol 36: 818-831.

27. Vaganov EA, Hughes MK, Kirdyanov AV et al (1999) Influence of snowfall and melt timing on tree growth in subarctic Eurasia. Nature 400: 149-151.

28. Anchukaitis KJ, Evans MN, Kaplan A et al (2006) Forward modeling of regional scale tree-ring patterns in the south-eastern United States and the recent influence of summer drought. Geophys Res Lett 33: L04705.

29. Evans MN, Reichert BK, Kaplan A et al (2006) A forward modeling approach to paleoclimatic interpretation of tree-ring data. J Geophys Res-Biogeo. 111: G03008.

30. Bräuning A, Mantwill B (2004) Summer temperature and summer monsoon history on the Tibetan 
plateau during the last 400 years recorded by tree rings. Geophys Res Lett 31: L24205.

31. Liang E, Shao X, Xu Y (2009) Tree-ring evidence of recent abnormal warming on the southeast Tibetan Plateau. Theor Appl Climatol 98: 9-18.

32. Wang Y, Li X, Dawadi B et al (2013) Phenological variation in height growth and needle unfolding of Smith fir along an altitudinal gradient on the southeastern Tibetan Plateau. Trees Struct Funct 27: 401-407.

33. Liang E,Wang Y, Eckstein D et al (2011) Little change in the fir tree-line position on the south-eastern Tibetan Plateau after 200 years of warming. New Phytol. 190: 760-769.

34. Miehe G, Miehe S, Vogel J et al (2007) Highest treeline in the northern hemisphere found in southern Tibet. Mount Res Devel 27: 169-173.

35. Li X, Liang E, Gričar J et al (2013) Age dependence of xylogenesis and its climatic sensitivity in Smith fir on the south-eastern Tibetan Plateau. Tree Physiol 33: 48-56.

36. Deslauriers A, Morin H, Begin Y (2003) Cellular phenology of annual ring formation of Abies balsamea in the Quebec boreal forest (Canada). Can J Forest Res 33: 190-200.

37. Camarero JJ, Olano JM, Parras A (2010) Plastic bimodal xylogenesis in conifers from continental Mediterranean climates. New Phytol 185: 471-480.

38. Rathgeber CBK, Rossi S, Bontemps JD (2011) Cambial activity related to tree size in a mature silver-fir plantation. Ann Bot 108: 429-438.

39. Rossi S, Deslauriers A, Gričar J et al (2008) Critical temperatures for xylogenesis in conifers of cold climates. Global Ecol Biogeogr 17: 696-707.

40. Monteith JL (1981) Climate variation and the growth of crops. Q J R Meteorolog Soc 107: 749-774.

41. Fritts H (1976) Tree rings and climate. Academic Press, New York.

42. Zhai L, Bergeron Y, Huang J et al (2012) Variation in intra-annual wood formation, and foliage and shoot development of three major Canadian boreal tree species. Am J Bot 99: 827-837.

43. Vaganov EA, Hughes MK, Shashkin AV (2006) Introduction and factors influencing the seasonal growth of trees. Springer, New York.

44. George SS, Meko DM, Evans MN (2008) Regional tree growth and inferred summer climate in the Winnipeg River basin, Canada, since AD 1783. Quaternary Res 70: 158-172.

45. Shi J, Liu Y,Vaganov E et al (2008) Statistical and process-based modeling analyses of tree 
growth response to climate in semi-arid area of north central China: A case study of Pinus tabulaeformis. J. Geophys Res-Biogeo 113: G01026.

46. Zhang YX, Shao XM, Xu Y, Wilmking M (2011) Process-based modeling analyses of Sabina przewalskii growth response to climate factors around the northeastern Qaidam Basin. Sci Bull 56: 1518-1525.

47. Gou X, Zhou F, Zhang Y et al (2013) Forward modeling analysis of regional scale tree-ring patterns around the northeastern Tibetan Plateau, Northwest China. Biogeo Discuss 2013: 9969-9988.

48. Oribe Y, Funada R, Shibagaki M et al (2001) Cambial reactivation in locally heated stems of the evergreen conifer Abies sachalinensis (Schmidt) Masters. Planta 212: 684-691.

49. Gričar J, Zupančič M, Čufar K et al (2006) Effect of local heating and cooling on cambial activity and cell differentiation in the stem of Norway spruce (Picea abies). Ann Bot 97: 943-951.

50.Huang JG, Deslauriers A, Rossi S (2014) Xylem formation can be modeled statistically as a function of primary growth and cambium activity. New Phytol 203: 831-841.

51. Wang ZY, Yang B, Deslauriers A et al (2015) Intra-annual stem radial increment response of Qilian juniper to temperature and precipitation along an altitudinal gradient in northwestern China. Trees - Struct Funct 29:25-34.

52. Lupi C, Morin H, Deslauriers A et al (2012) Xylogenesis in black spruce: does soil temperature matter? Tree Physiol 32: 74-82.

53. Hosoo Y, Yoshida M, Imai T et al (2002) Diurnal difference in the amount of immunogold-labeled glucomannans detected with field emission scanning electron microscopy at the innermost surface of developing secondary walls of differentiating conifer tracheids. Planta 215: 1006-1012.

54. Steppe K, Sterck F, Deslauriers A (2015) Diel growth dynamics in tree stems: linking anatomy and ecophysiology. Trends Plant Sci 20: 335-343.

55. Dünisch O (2010) Low night temperatures cause reduced tracheid expansion in Podocarpus latifolius. IAWA J 31: 245-255. https://doi.org/10.1163/22941932-90000020

56. Boulouf Lugo J, Deslauriers A, Rossi S (2012) Duration of xylogenesis in black spruce lengthened between 1950 and 2010. Ann Bot 110: 1099-1108.

57. Körner C (2015) Paradigm shift in plant growth control. Curr Opin Plant Biol 25: 107-114. 
463

464

465

466

467

468

469

470

471

472

473

474

475

476

477

478

479

480

481

482

483

484

485
58. Li M, Xiao W, Wang S et al (2008) Mobile carbohydrates in Himalayan treeline trees I. Evidence for carbon gain limitation but not for growth limitation. Tree Physiol 28: 1287-1296.

59. Wiley E, Helliker B (2012) A re-evaluation of carbon storage in trees lends greater support for carbon limitation to growth. New Phytol 195: 285-289. 
Table 1 Mean ( \pm standard deviation) of the threshold daily maximum (MaxT), mean (MeanT) 487 and minimum (MinT) temperatures for the onset and ending of xylogenesis.

488

\begin{tabular}{|c|c|c|c|c|c|c|c|}
\hline \multirow[b]{2}{*}{ Site } & \multirow[b]{2}{*}{ Year } & \multicolumn{3}{|c|}{ Onset of xylogenesis } & \multicolumn{3}{|c|}{ Ending of xylogenesis } \\
\hline & & $\operatorname{MinT}\left({ }^{\circ} \mathrm{C}\right)$ & MeanT $\left({ }^{\circ} \mathrm{C}\right)$ & $\operatorname{MaxT}\left({ }^{\circ} \mathrm{C}\right)$ & $\operatorname{MinT}\left({ }^{\circ} \mathrm{C}\right)$ & MeanT $\left({ }^{\circ} \mathrm{C}\right)$ & $\operatorname{MaxT}\left({ }^{\circ} \mathrm{C}\right)$ \\
\hline \multirow[t]{4}{*}{1} & 2007 & $0.6 \pm 0.2$ & $4.3 \pm 0.1$ & $9.7 \pm 0.4$ & $0.8 \pm 0.3$ & $3.9 \pm 0.3$ & $9.0 \pm 0.4$ \\
\hline & 2008 & $0.8 \pm 0.2$ & $3.7 \pm 0.3$ & $8.9 \pm 0.4$ & $0.6 \pm 0.2$ & $3.5 \pm 0.2$ & $8.7 \pm 0.1$ \\
\hline & 2009 & $0.8 \pm 0.3$ & $4.4 \pm 0.1$ & $9.8 \pm 0.2$ & $1.1 \pm 0.1$ & $4.7 \pm 0.1$ & $9.9 \pm 0.1$ \\
\hline & 2010 & $0.3 \pm 0.1$ & $3.4 \pm 0.2$ & $9.1 \pm 0.3$ & $0.4 \pm 0.1$ & $2.9 \pm 0.3$ & $8.0 \pm 0.2$ \\
\hline \multirow[t]{3}{*}{2} & 2007 & $0.5 \pm 0.3$ & $4.3 \pm 0.2$ & $9.4 \pm 0.5$ & $0.9 \pm 0.4$ & $4.1 \pm 0.5$ & $9.3 \pm 0.6$ \\
\hline & 2008 & $1.0 \pm 0.3$ & $3.9 \pm 0.3$ & $8.7 \pm 0.4$ & $0.7 \pm 0.3$ & $3.6 \pm 0.2$ & $8.7 \pm 0.1$ \\
\hline & 2009 & $0.8 \pm 0.3$ & $4.4 \pm 0.4$ & $9.8 \pm 0.2$ & $1.1 \pm 0.3$ & $4.5 \pm 0.4$ & $9.8 \pm 0.3$ \\
\hline
\end{tabular}

489

490

491

492

493

494

495

496

497

498

499

500

501 
502 Table 2 Mean ( \pm standard deviation) of degree-day sums $\left(\geq 5^{\circ} \mathrm{C}\right)$ at onset of xylogenesis, 503 number of days from the date of snow melting (Date snow $)$ and soil thawing (Date soil $)$ to the 504 onset date of xylogenesis (Date xylogenesis ).

\begin{tabular}{lllll}
\hline & Year & $\begin{array}{l}\text { Degree-day sum at } \\
\text { onset of xylogenesis } \\
\text { (DD) }\end{array}$ & $\begin{array}{l}\text { Number of days } \\
\text { between Date }\end{array}$ & $\begin{array}{l}\text { Number of days } \\
\text { and Date }\end{array}$ \\
& & & $\begin{array}{l}\text { between } \\
\text { (days) }\end{array}$ & Date $_{\text {xylem }}$ (days) \\
& & & $4 \pm 5$ & \\
\hline Site 1 & 2007 & $41 \pm 13$ & $18 \pm 3$ & $4 \pm 3$ \\
& 2008 & $11 \pm 0$ & $29 \pm 3$ & $6 \pm 3$ \\
& 2009 & $8 \pm 2$ & $46 \pm 3$ & $11 \pm 3$ \\
& 2010 & $8 \pm 3$ & $6 \pm 5$ & $6 \pm 3$ \\
\hline Site 2 & 2007 & $34 \pm 20$ & $21 \pm 4$ & $9 \pm 5$ \\
& 2008 & $13 \pm 12$ & $29 \pm 3$ & $11 \pm 3$ \\
\hline
\end{tabular}

505

506

507

508

509

510

511

512

513

514

515

516 
517 Table 3 The best-fit parameter estimates for the VS model used in this study.

\begin{tabular}{|c|c|c|}
\hline Model parameter & Description(unit) & Value \\
\hline $\mathrm{CT}_{\min }$ & Minimum temperature for tree growth $\left({ }^{\circ} \mathrm{C}\right)$ & 0.9 \\
\hline $\mathrm{T}_{\text {opt1 }}$ & Lower end of range of optimal temperatures $\left({ }^{\circ} \mathrm{C}\right)$ & 5.9 \\
\hline $\mathrm{T}_{\mathrm{opt} 2}$ & Upper end of range of optimal temperatures & 9.3 \\
\hline $\mathrm{T}_{\max }$ & Maximum temperature for tree growth $\left({ }^{\circ} \mathrm{C}\right)$ & 19.9 \\
\hline $\mathrm{W}_{\min }$ & Minimum soil moisture for tree growth (v/v) & 0.06 \\
\hline $\mathrm{W}_{\mathrm{opt} 1}$ & Lower end of range of optimal soil moisture (v/v) & 0.18 \\
\hline $\mathrm{W}_{\mathrm{opt} 2}$ & Upper end of range of optimal soil moisture (v/v) & 0.22 \\
\hline $\mathrm{W}_{\max }$ & Maximum soil moisture for tree growth (v/v) & 0.50 \\
\hline $\mathrm{T}_{\text {beg }}$ & Temperature sum for initiation of growth $\left({ }^{\circ} \mathrm{C}\right)$ & 30 \\
\hline$D_{\text {root }}$ & Depth of root system (mm) & 50 \\
\hline $\mathrm{P}_{\max }$ & Maximum daily precipitation for saturated soil (mm) & 20 \\
\hline $\mathrm{K}_{1}$ & Fraction of precipitation penetrating soil (dimensionless) & 0.86 \\
\hline $\mathrm{K}_{2}$ & First coefficient for calculation of transpiration (mm/day) & 0.12 \\
\hline $\mathrm{K}_{3}$ & Second coefficient for calculation of transpiration $\left(1 /{ }^{\circ} \mathrm{C}\right)$ & 0.175 \\
\hline $\mathrm{K}_{\mathrm{r}}$ & Coefficient for water infiltration from soil (dimensionless) & 0.006 \\
\hline
\end{tabular}




\section{Figure captions:}

521 Fig. 1 Micrometeorological conditions (2007 - 2010) at the upper treeline in the Sygera Mts.,

522 southeastern Tibetan Plateau, showing (a) daily mean air temperature and daily total

523 precipitation, (b) daily soil temperature (at depths of 10, 20 and $40 \mathrm{~cm}$ ) and snow depth, and

524 (c) daily mean soil volumetric moisture contents (at depths of 10, 20 and $40 \mathrm{~cm}$ ).

525

526 Fig. 2 Onset (a), ending (b), and duration (c) of xylem formation of Smith fir (Abies georgei

527 var. smithii) based on weekly xylogenesis observations at site 1 (4360 m a.s.l.) (grey columns)

528 and site 2 (4250 $\mathrm{m}$ a.s.l.) (white columns). Error bars indicate standard deviations among 529 trees.

530

531 Fig. 3 Lagged (0-10 days) Pearson correlation coefficients between xylem cell production (a,

b), growth index (c, d), and corresponding climatic variables. P0 represents the weekly

533

climatic mean for the exact period between two sampling dates. P1 to P10 represent the weekly means lagged 1-10 days before the sampling date. Dotted horizontal lines show the 95\% confidence limits. Abbreviations: MaxT = maximum temperature, MeanT= mean temperature, MinT= minimum temperature, $\mathrm{P}=$ precipitation, and GGD = growing degree days above $5^{\circ} \mathrm{C}$.

539 Fig. 4 Critical minimum (black dots), mean (white dots), and maximum (grey dots) air

540 temperatures at sites 1 and 2, corresponding with the 0.5-probability of the onset and ending 
541 of xylem formation according to xylogenesis observations in Smith fir. Error bars indicate the

542 standard deviation among trees.

543

544 Fig. 5 Observed (solid line) and simulated (dashed line) tree-ring width indices at Smith fir

545 treeline in the Sygera Mts. on the southeastern Tibetan Plateau, 1960-2006.

546

547 Fig. 6 Pearson correlation coefficients between the observed and estimated values of tree-ring

548 width for different estimates of $\mathrm{CT}_{\min }$.

549

550 

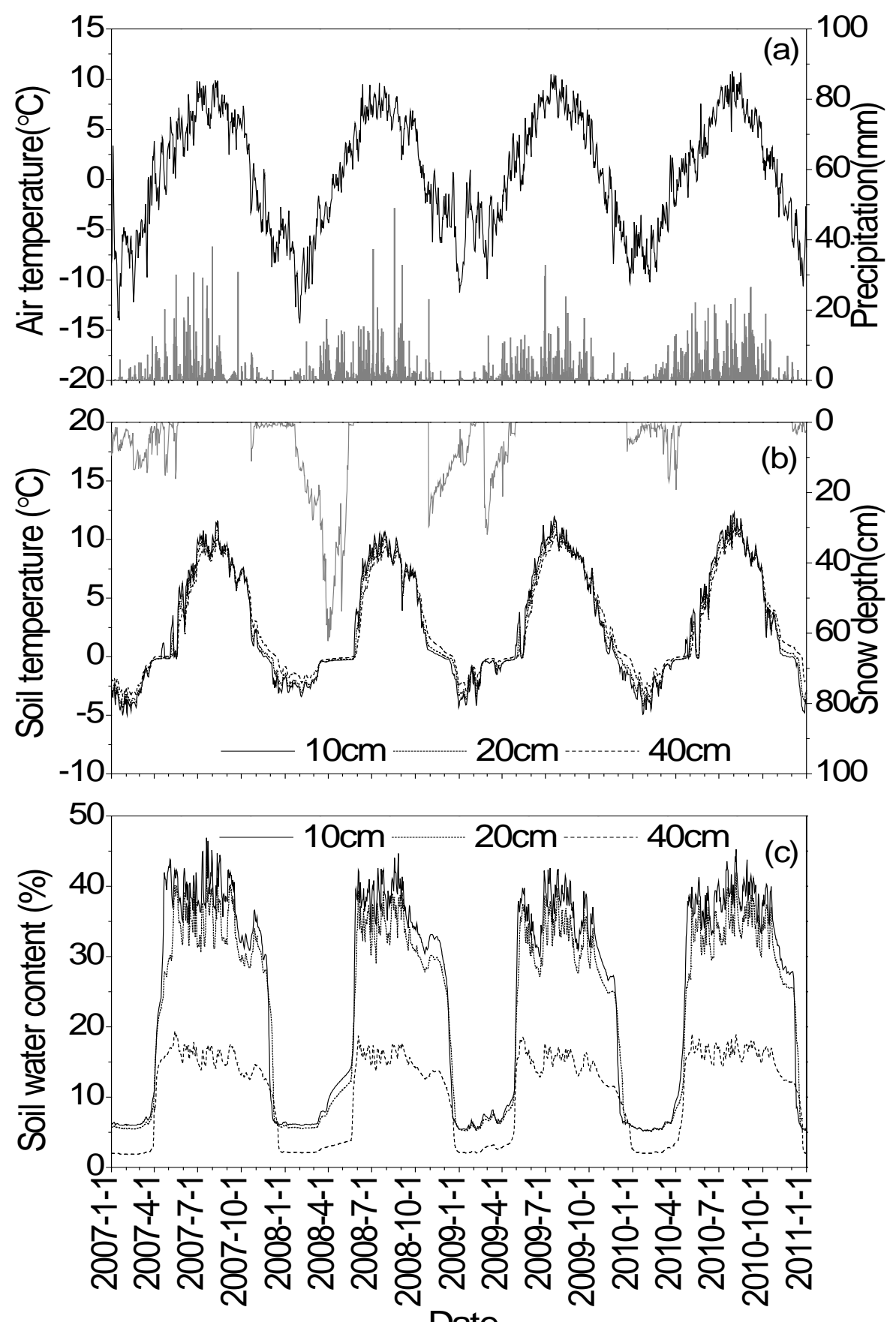

Fig. 1 

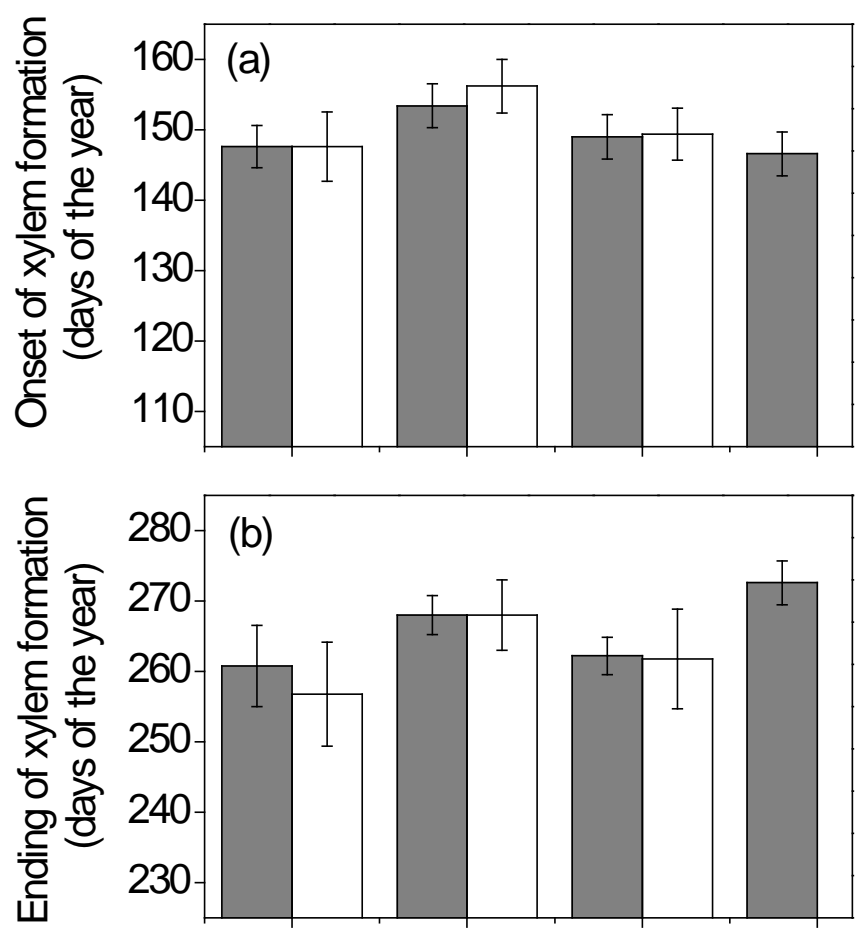

554

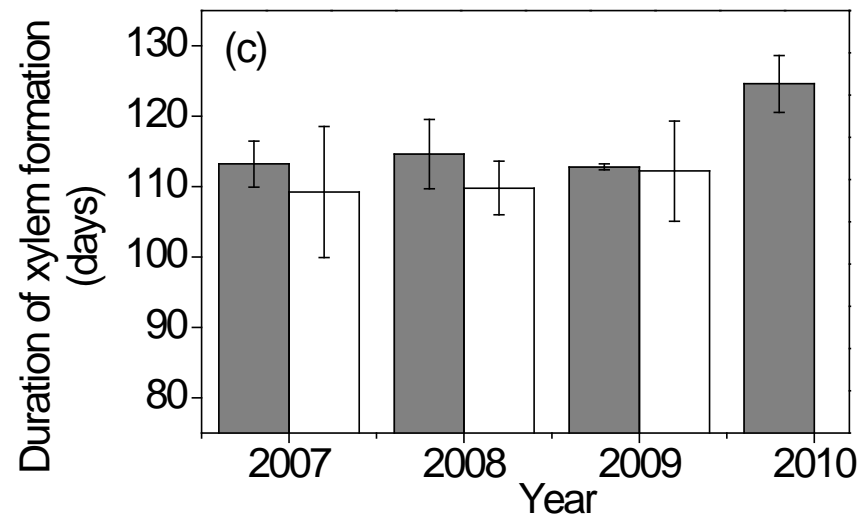

$555 \quad$ Fig. 2

556

557

558

559

560

561

562 


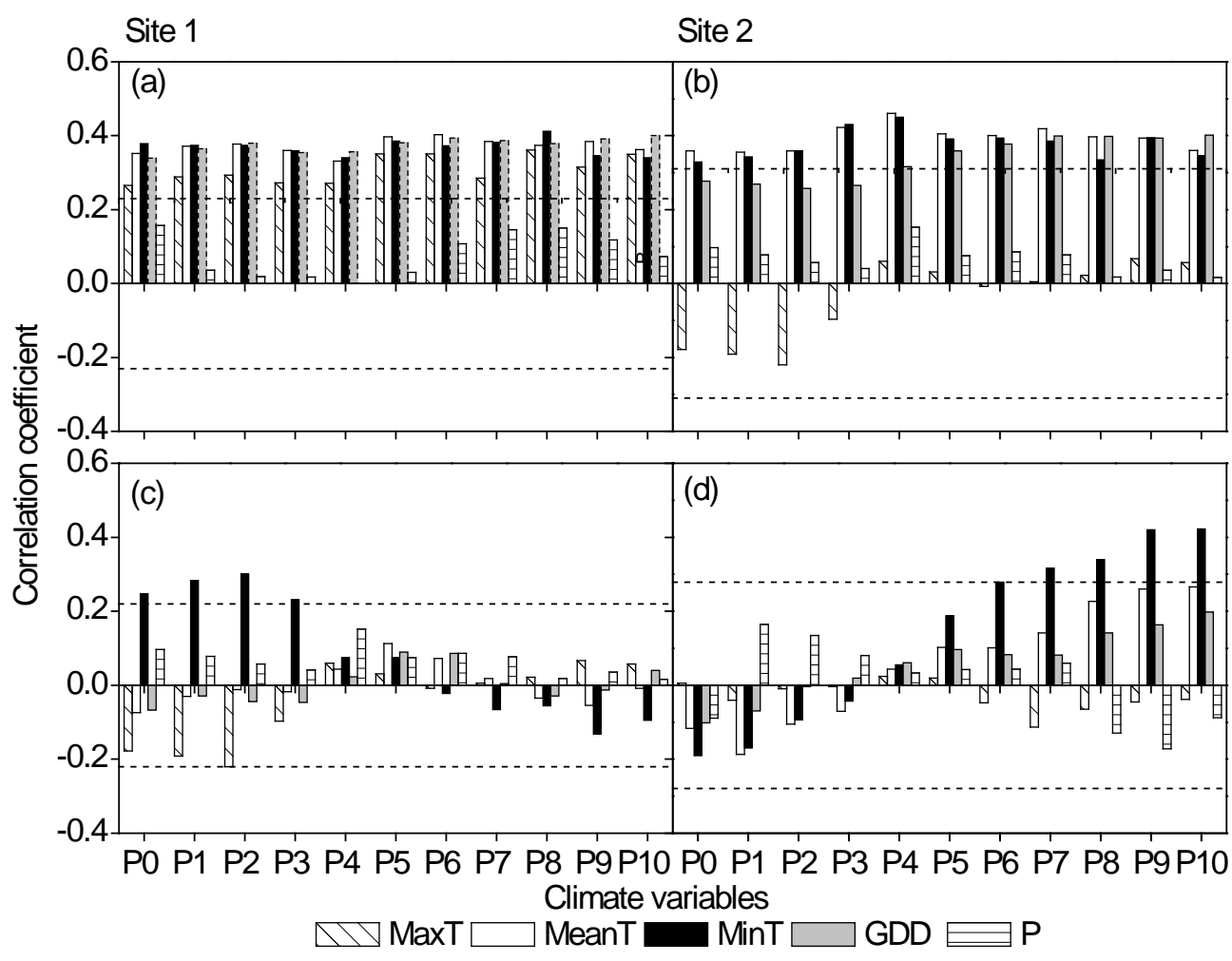

Fig. 3

567

568

569

570

571

572

573

574

575

576 


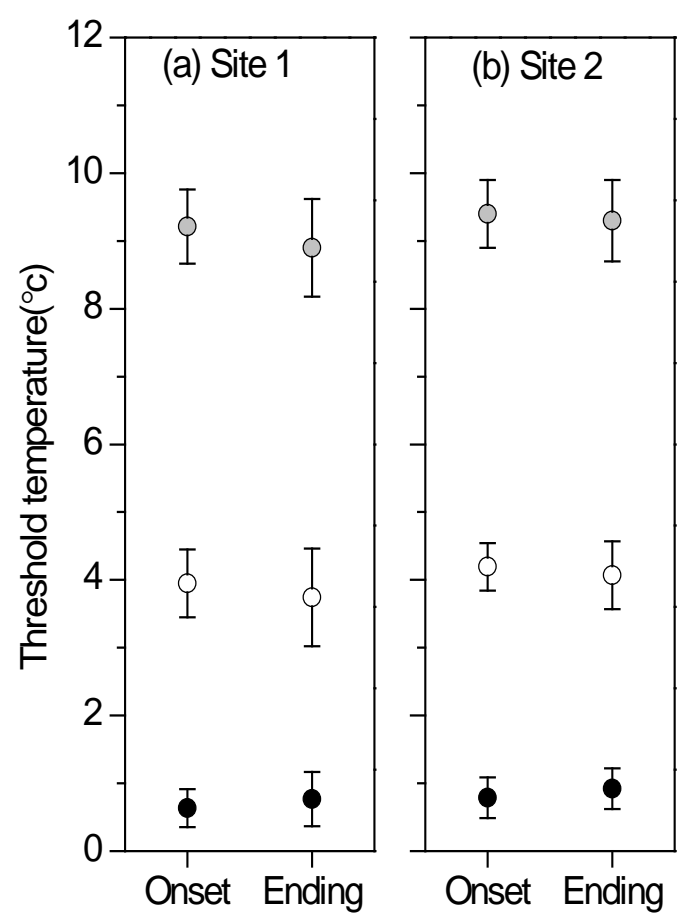

$579 \quad$ Fig. 4

580

581

582

583

584

585

586

587

588

589

590 


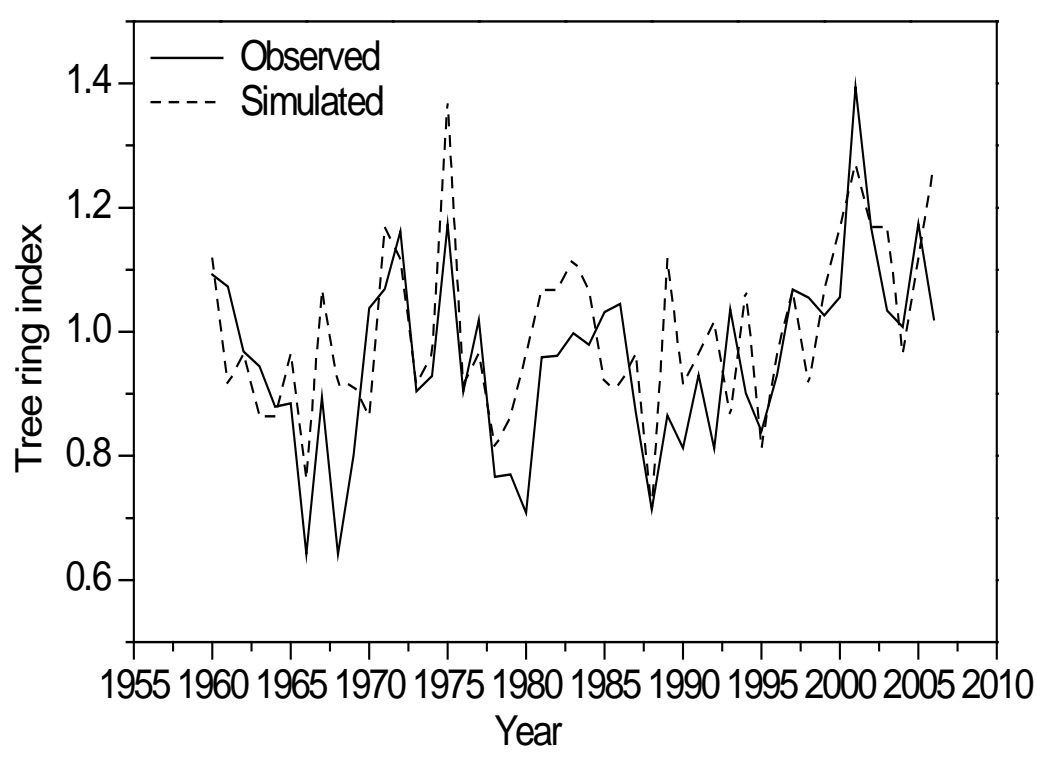

$593 \quad$ Fig. 5

594

595

596

597

598

599

600

601

602

603

604

605

606 
607

608

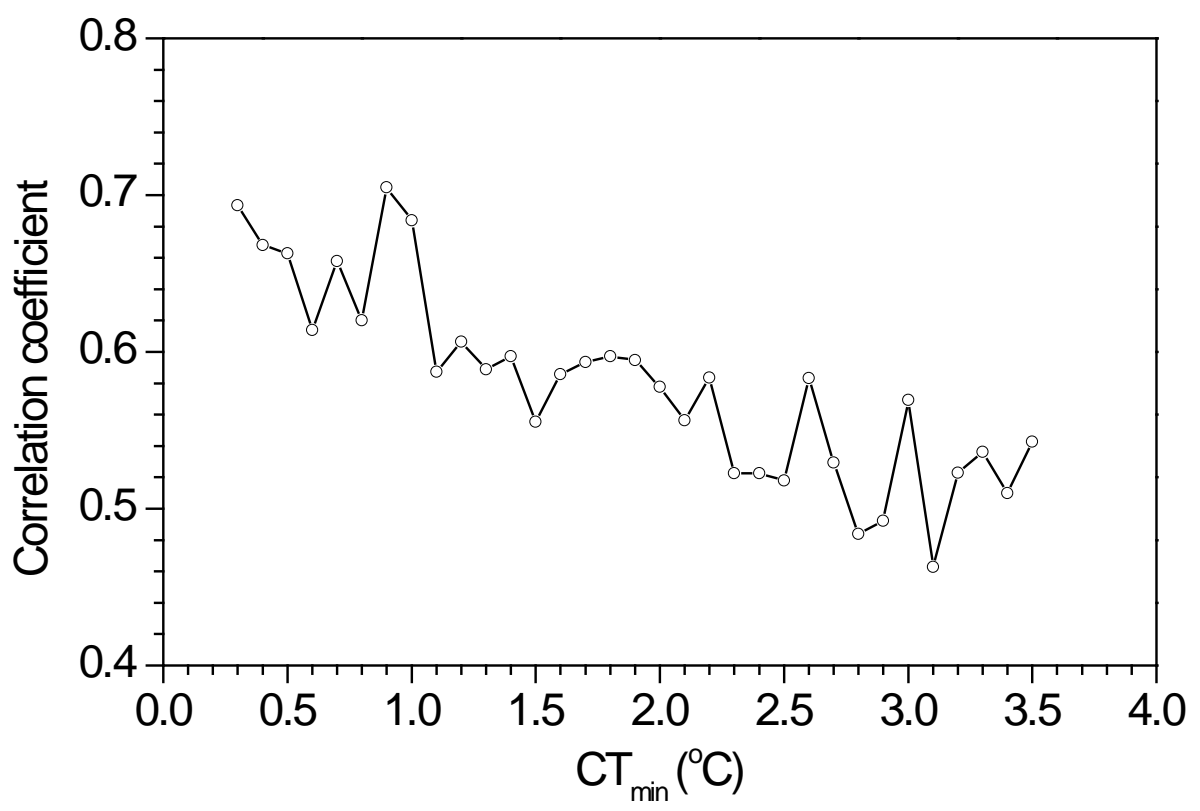

609

$610 \quad$ Fig. 6

611

612 
2 Table S1 Parameters of the Gompertz function (A,,,$K), R^{2}$ and day of the inflection 3 point (tp) for Smith fir growing at two treeline sites, 2007 - 2010.

\begin{tabular}{lllllll}
\hline & Year & A & ß & $\mathrm{K}\left(10^{-2}\right)$ & tp & $R^{2}$ \\
\hline Site 1 & 2007 & 23.95 & 5.48 & 3.25 & 170.59 & 0.98 \\
& 2008 & 22.97 & 5.97 & 3.32 & 179.32 & 0.96 \\
& 2009 & 25.68 & 7.07 & 4.08 & 174.50 & 0.96 \\
& 2010 & 21.08 & 5.67 & 3.25 & 176.67 & 0.99 \\
& & & & & & \\
Site 2 & 2007 & 24.79 & 5.03 & 2.85 & 176.56 & 0.98 \\
& 2008 & 21.22 & 6.97 & 3.87 & 178.13 & 0.98 \\
& & & & & & \\
& 2009 & 23.62 & 5.70 & 3.02 & 188.53 & 0.98 \\
\hline
\end{tabular}

4

5

6

7

8

9

10

11

12

13

14 


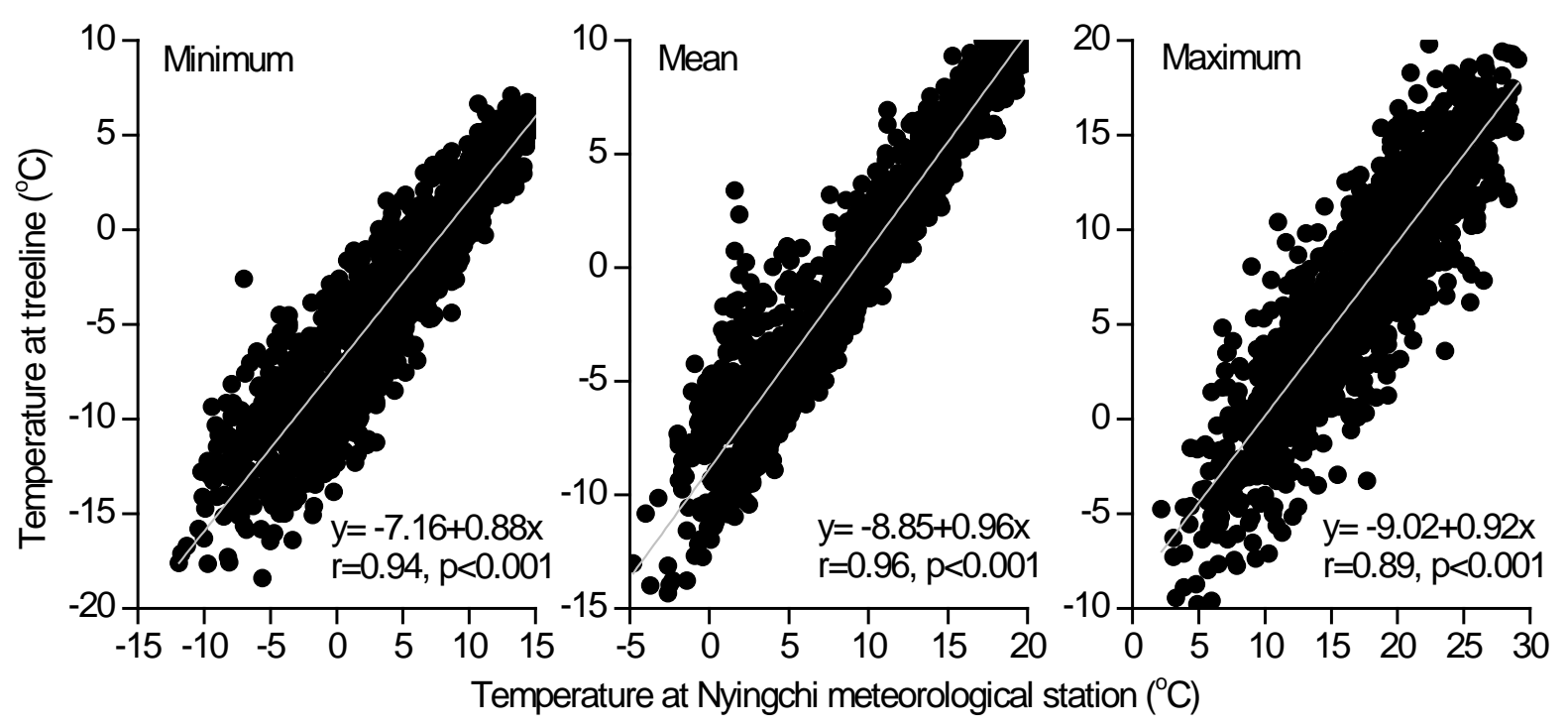

16 Fig. S1. Plots of the daily minimum, mean, and maximum temperature from automatic

17 weather stations at treeline in the Sygera Mountains and at the Nyingchi meteorological

18 station from January 1, 2007 to December 31, 2010. 


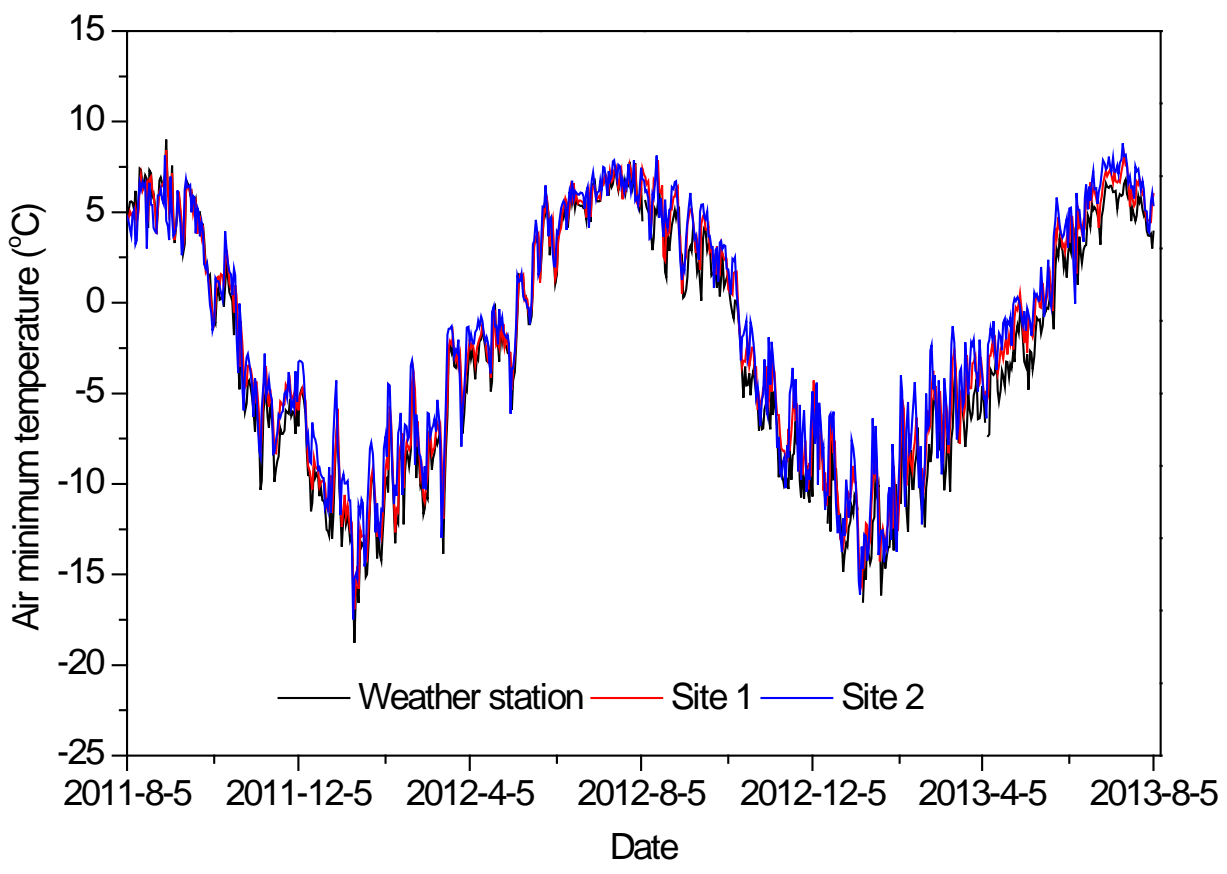

22 Fig. S2. Minimum air temperatures recorded by the automatic weather station (black line)

23 and temperature data logger (TidbiT v2 Temp UTBI-001, Onset Computer Corporation,

24 Bourne, MA, USA) at site 1 (red line) and site 2 (blue line) from August 5, 2011 to August 5, 252013.

26 
Site 1
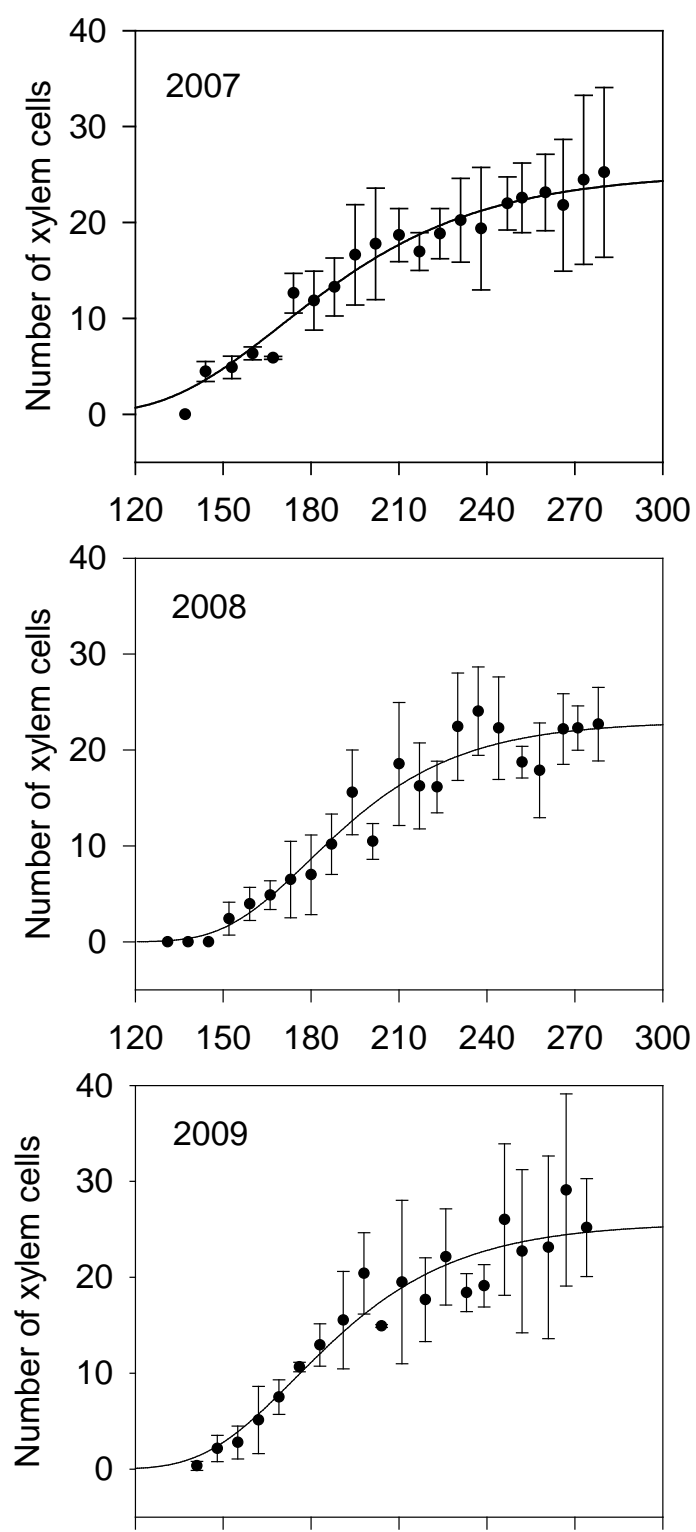

$\begin{array}{lllllll}120 & 150 & 180 & 210 & 240 & 270 & 300\end{array}$

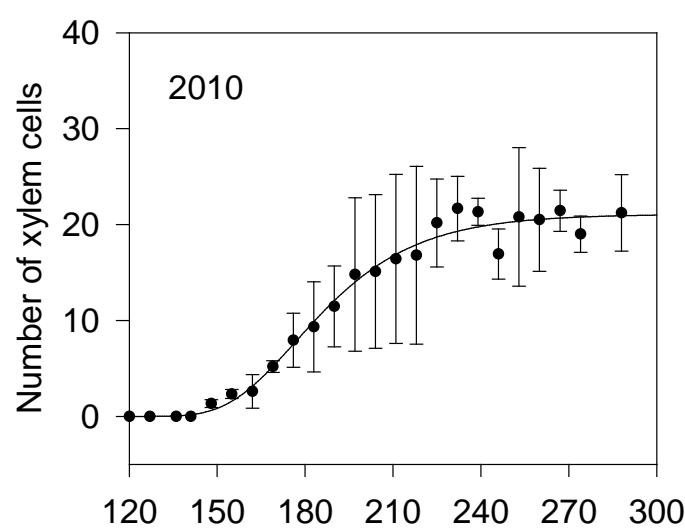

Day of the year
Site 2
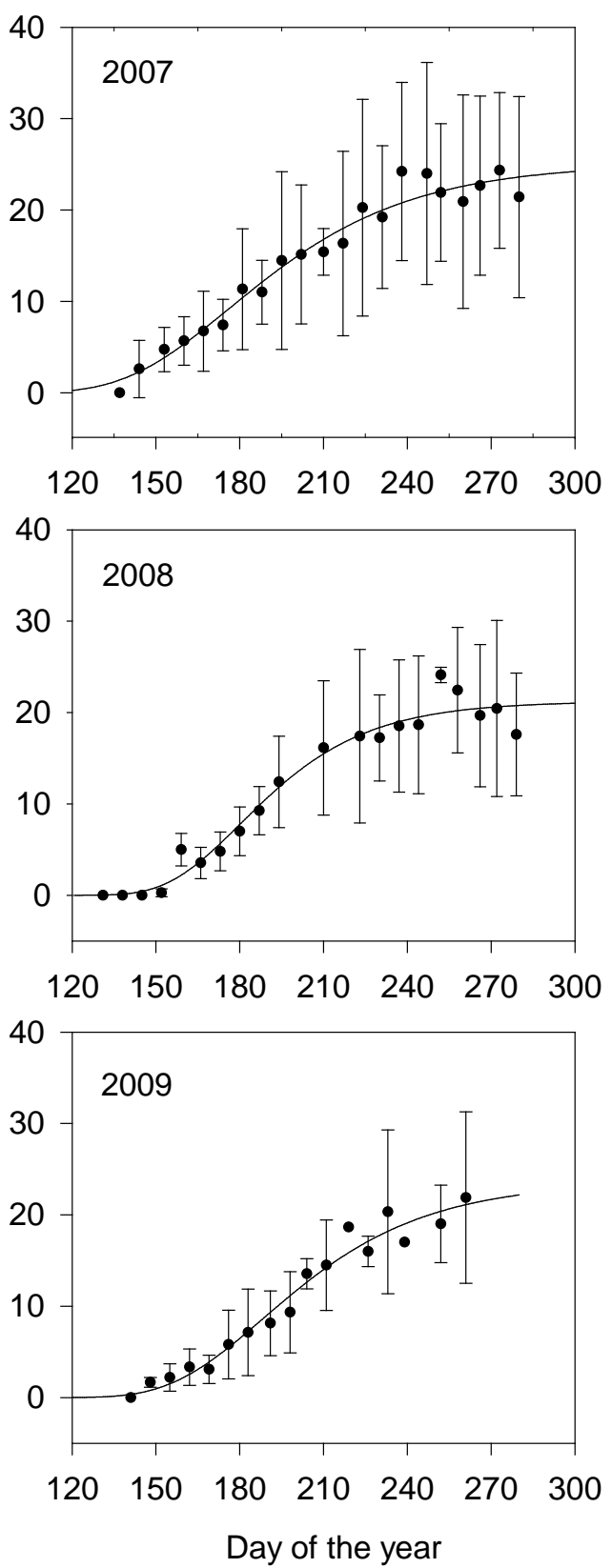

28 Fig. S3. Dynamics of xylem growth (including enlarging, wall thickening, and mature xylem

29 cells) at two Smith fir treelines as modeled using a Gompertz function. 


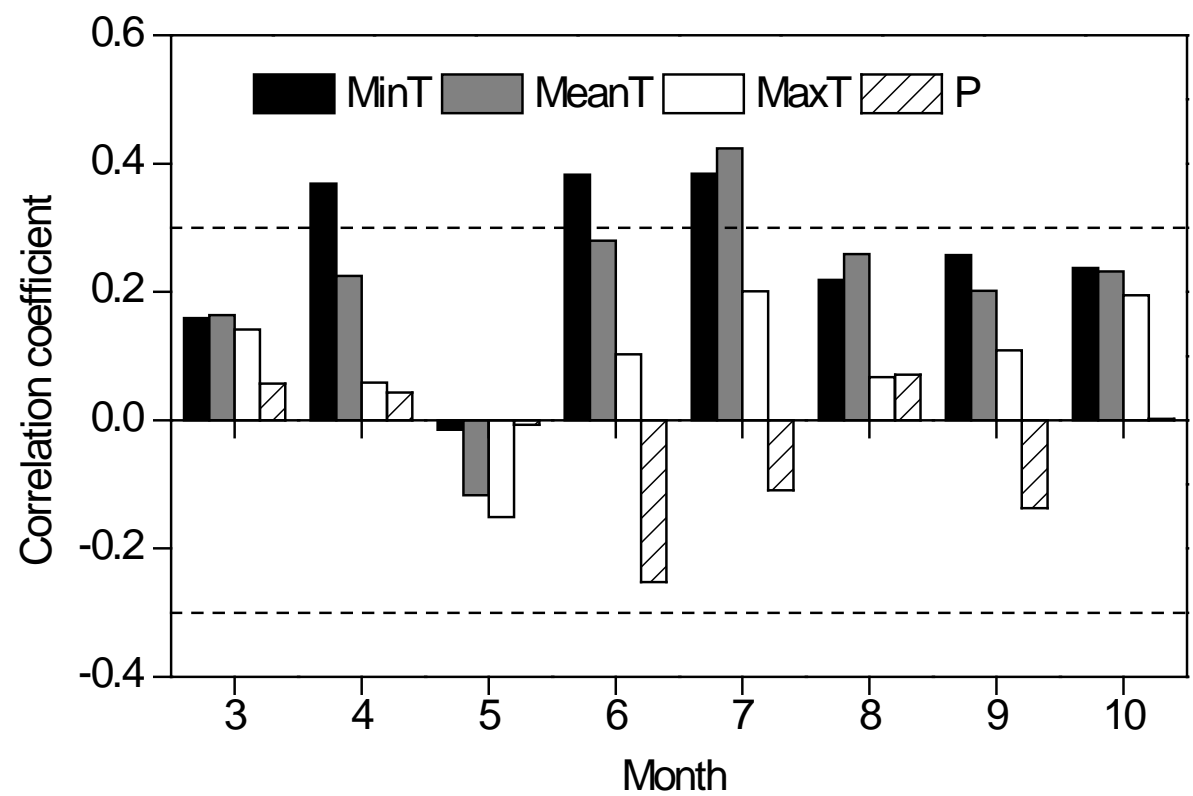

33 Fig. S4. Correlations between the simulated tree ring chronology and monthly temperature

34 and precipitation at Smith fir treeline in the Sygera Mountains on the southeastern Tibetan

35 Plateau. Dotted horizontal lines show the 95\% confidence limits. Abbreviations: MaxT = maximum temperature, MeanT= mean temperature, $\mathrm{MinT}=$ minimum temperature and $\mathrm{P}=$ precipitation. 